\title{
Repressão, autonomia e responsividade: o direito que se exerce nas delegacias de polícia no Brasil*
}

\author{
Ludmila Mendonça Lopes Ribeiro** \\ \& Igor Suzano Machado***
}

Resumo: Neste artigo, trataremos das relações entre sociedade e Estado a partir da utilização das ideias de direito repressivo, autônomo e responsivo, de Nonet e Selznick, para entender as transformações operacionalizadas no âmbito da polícia civil de três estados brasileiros - São Paulo, Rio de Janeiro e Pernambuco - em razão da pesquisa "Semana de visitas a delegacias de polícia", que avalia os distritos policiais em termos de orientação para a comunidade, as condições materiais, o tratamento igualitário da população, a transparência e prestação de contas, as condições de detenção e, ao final, discute com os delegados os resultados obtidos, viabilizando a transformação da forma como o serviço policial é oferecido à população. A partir dos dados coletados em 64 delegacias de polícia visitadas em Pernambuco, São Paulo e Rio de Janeiro, em três anos consecutivos (entre 2009 e 2011) e, considerando a melhoria na qualidade do atendimento prestado à população, problematizamos como a polícia tem se tornado mais permeável e responsiva à população, apesar da permanência de fortes traços repressivos, como o peso da função de manutenção da ordem e de uma política de segredo do trabalho policial em torno do funcionamento das instituições.

Palavras-chave: direito responsivo; direito repressivo; delegacias de polícia; "Semana de visitas a delegacias de polícia”.

\section{Introdução}

$\mathrm{N}$ este artigo, trataremos das relações entre sociedade e Estado a partir da utilização das ideias de direito repressivo, autônomo e responsivo, de Nonet e Selznick (2010), ${ }^{1}$ para entender as transformações operacionalizadas no âmbito da polícia civil de três estados brasileiros - São Paulo, Rio de Janeiro e Pernambuco - em razão da pesquisa "Semana de visitas a delegacias de polícia", que avalia os distritos policiais em termos de orientação para a comunidade, as condições materiais, o tratamento igualitário da população, a transparência e prestação de contas, as condições de detenção e, ao final, discute com os delegados os resultados obtidos, viabilizando a transformação da forma como o serviço policial é oferecido à população.

A "Semana de visitas a delegacias de polícia" é coordenada pela Aliança Global Altus, que reúne importantes centros de pesquisa que trabalham com os temas da violência e da segurança pública e que se localizam em diferentes países (Rússia,

\author{
* Uma primeira \\ versão deste artigo \\ foi apresentada \\ ao VIII Encontro \\ da Associação \\ Brasileira de Ciência \\ Política, realizado \\ em agosto de 2012, \\ em Gramado. \\ Agradecemos aos \\ debatedores do \\ trabalho naquela \\ ocasião e aos \\ pareceristas \\ anônimos da Revista \\ Sociedade e Estado \\ os comentários \\ valiosos que levaram \\ à edição final, revista \\ e reformulada, ora \\ publicada.

\section{** Professora do de Sociologia e Antropologia da Universidade Federal de Minas Gerais. <ludmila.ribeiro@ gmail.com>.} \\ Departamento
}

*** Professor do Instituto de Estudos Sociais e Políticos da Universidade do Estado do Rio de Janeiro. <igorsuzano@gmail. com>.

1. Philippe Nonet
nasceu e cresceu
na Bélgica, onde se
tornou doutor em
direito. Seu interesse
pelas ciências
sociais é despertado
ao ingressar na
Universidade de
Berkeley (1961) e
começa a estudar e

1. Philippe Nonet nasceu e cresceu na Bélgica, onde se pelas ciências ao ingressar na Berkeley (1961) começa a estudar e 
ensinar sociologia. É neste contexto que ele conhece Philip Selznick, também professor em Berkeley e especialista na área de sociologia das organizações. Os dois autores também produziram anteriormente outra obra sobre o tema, em colaboração com Howard Vollmer: Law, society, and industrial justice (New York: Russell Sage Foundation, 1969). Em ambos os casos, os livros são considerados clássicos da sociologia jurídica por contribuírem com os pesquisadores na compreensão do funcionamento de instituições com funções eminentemente judiciárias, tais como as polícias, o Ministério Público, a Defensoria Pública e o Judiciário. Exatamente por isso, o livro não pode ser considerado como uma referência teórica estritamente jurídica, mas como paradigma para estudos sociológicos realizados na área.

\section{Em razão do} treinamento que é concedido aos visitantes, a metodologia empregada na coleta de dados é bastante semelhante, em termos de princípios, à etnometodologia. Para verificar essa discussão, cf. Ribeiro e Silva (2011).

3. A primeira edição do livro é de 1978.
Índia, Nigéria, Estados Unidos, Chile e Brasil). O Centro de Estudos de Segurança e Cidadania da Universidade Cândido Mendes (CESeC/Ucam) é o representante da Altus no Brasil.

A grande inovação da "Semana de visitas a delegacias de polícia" é o fato de o trabaIho não ser apenas um projeto de pesquisa, mas também uma forma de intervenção social, uma vez que são os cidadãos que se dirigem até o distrito policial coletam informações sobre o seu funcionamento. ${ }^{2}$ Além disso, os resultados são discutidos com os policiais, para que esses possam compreender melhor o significado dos dados coletados e, ainda, sobre o que pode ser feito para a melhoria do serviço prestado. Nesses workshops, os delegados são convidados a preencher um formulário de avaliação, no qual devem expressar em que medida a pesquisa-ação contribui (ou não) para o entendimento das maiores deficiências do serviço policial e para a melhoria da qualidade do atendimento prestado à população.

A partir dos dados coletados em 64 delegacias de polícia visitadas em Pernambuco, São Paulo e Rio de Janeiro, em três anos consecutivos (entre 2009 e 2011) e, considerando a melhoria da qualidade do atendimento prestado à população, problematizamos como a polícia tem se tornado mais permeável e responsiva à população, apesar da permanência de fortes traços repressivos, como o peso da função de manutenção da ordem e de uma política de segredo do trabalho policial em torno do funcionamento das instituições.

\section{Sobre direito repressivo, autônomo e responsivo}

O referencial teórico deste trabalho é a obra Direito e sociedade: a transição ao sistema jurídico responsivo, de Philippe Nonet e Philip Selznick. Apesar de escrita há mais de 30 anos, apenas recentemente foi traduzida para o português, o que, contudo, condiz com o momento histórico que o Brasil vivencia. Isso porque, conforme destacado por Werneck Vianna e Eisenberg no "Prefácio" à edição brasileira, os problemas enfrentados pelo direito nos Estados Unidos das décadas de 1960 e $1970^{3}$ só vieram a ser conhecidos em nossa realidade muitos anos depois, com a promulgação da Constituição de 1988 e, especialmente, nos anos que se seguiram, com a maior assimilação de seus temas e procedimentos. Sendo assim, mesmo que não seja desprezível a demora na publicação da edição brasileira, isso não impede que o livro chegue ao público num momento em que suas reflexões ocupam o centro do debate sobre os rumos que a Justiça e o direito devem seguir no Brasil.

A obra apresenta uma sociologia do direito que identifica no fenômeno jurídico três tipos ideais que se sucedem evolutivamente no tempo, respondendo a demandas sociais específicas. Segundo os autores, esses três tipos seriam o direito repressivo, 
o direito autônomo e o direito responsivo. ${ }^{4}$ De maneira sucinta, pode-se dizer que os três direitos são caracterizados por Nonet e Selznick da seguinte forma (Quadro 1):

\section{QUADRO 1}

CARACTERÍSTICAS DOS TRÊS DIREITOS QUANTO À FINALIDADE, AO SISTEMA DE LEGITIMAÇÃO, AO SISTEMA NORMATIVO, AO TIPO DE RACIONALIDADE JURÍDICA, AO USO DA COERÇÃO, À RELAÇÃO COM A MORAL E A POLÍTICA E ÀS EXPECTATIVAS DE OBEDIÊNCIA E PARTICIPAÇÃO POPULARES

\begin{tabular}{|c|c|c|c|}
\hline & Direito repressivo & Direito autônomo & Direito responsivo \\
\hline $\begin{array}{l}\text { Finalidade do } \\
\text { direito }\end{array}$ & Ordem & Legitimação & $\begin{array}{l}\text { Competência (capacidade de resolver } \\
\text { problemas) }\end{array}$ \\
\hline Legitimidade & $\begin{array}{l}\text { Segurança social e } \\
\text { razão de Estado }\end{array}$ & Procedimentos equânimes & Justiça substantiva \\
\hline $\begin{array}{l}\text { Sistema } \\
\text { normativo }\end{array}$ & $\begin{array}{l}\text { Pouco elaborado, } \\
\text { ainda que detalhado; } \\
\text { pouco capaz de sujeitar } \\
\text { governantes }\end{array}$ & $\begin{array}{l}\text { Elaborado, obrigando a } \\
\text { sujeição tanto de governantes } \\
\text { quanto de governados }\end{array}$ & $\begin{array}{l}\text { Subordinado a princípios e a políticas } \\
\text { institucionalizadas }\end{array}$ \\
\hline $\begin{array}{l}\text { Racionalidade } \\
\text { jurídica }\end{array}$ & $\begin{array}{l}\text { Casuística e } \\
\text { particularista }\end{array}$ & $\begin{array}{l}\text { Forte aderência à autoridade } \\
\text { legal; vulnerável ao formalismo } \\
\text { e legalismo }\end{array}$ & $\begin{array}{l}\text { Orientada a fins; ampliação da } \\
\text { competência cognitiva }\end{array}$ \\
\hline Discricionariedade & Difusa, oportunista & $\begin{array}{l}\text { Restrita à interpretação das } \\
\text { normas; baixa delegação }\end{array}$ & $\begin{array}{l}\text { Ampla, mas subordinada à } \\
\text { justificação dos fins }\end{array}$ \\
\hline Coerção & $\begin{array}{l}\text { Extensiva, com poucos } \\
\text { limites }\end{array}$ & Controlada por limites legais & $\begin{array}{l}\text { Busca de alternativas baseadas em } \\
\text { incentivos pedagógicos }\end{array}$ \\
\hline Moralidade & $\begin{array}{l}\text { Moralidade comunal; } \\
\text { legalismo moral; "moral } \\
\text { de coação" }\end{array}$ & $\begin{array}{l}\text { Moralidade institucional; } \\
\text { preocupada com a eticidade do } \\
\text { processo legal }\end{array}$ & $\begin{array}{l}\text { Moralidade civil; "moral de } \\
\text { cooperação" }\end{array}$ \\
\hline Política & $\begin{array}{l}\text { Direito subordinado ao } \\
\text { poder político }\end{array}$ & $\begin{array}{l}\text { Direito independente da } \\
\text { política; separação entre } \\
\text { poderes }\end{array}$ & $\begin{array}{l}\text { Integração de aspirações legais e } \\
\text { políticas, continuação entre poderes }\end{array}$ \\
\hline $\begin{array}{l}\text { Expectativas de } \\
\text { obediência }\end{array}$ & $\begin{array}{l}\text { Incondicional; } \\
\text { desobediência punida } \\
\text { como rebeldia }\end{array}$ & $\begin{array}{l}\text { Condicionada; desobediência } \\
\text { justificada apenas com amparo } \\
\text { legal }\end{array}$ & $\begin{array}{l}\text { Desobediência avaliada em termos } \\
\text { de danos efetivos; percebida como } \\
\text { portadora de temas emergentes a } \\
\text { serem legitimados }\end{array}$ \\
\hline Participação & $\begin{array}{l}\text { Consentimento } \\
\text { passivo; crítica como } \\
\text { manifestação de } \\
\text { deslealdade }\end{array}$ & $\begin{array}{l}\text { Acesso limitado pelos } \\
\text { procedimentos estabelecidos; } \\
\text { emergência da crítica ao } \\
\text { sistema jurídico }\end{array}$ & $\begin{array}{l}\text { Acesso ampliado pela integração dos } \\
\text { grupos defensores de causas sociais } \\
\text { na esfera política com os grupos que } \\
\text { atuam com o mesmo propósito na } \\
\text { esfera judicial }\end{array}$ \\
\hline
\end{tabular}

Fonte: Nonet e Selznick, 2010 [1978]: 57.
4. É importante chamar a atenção para a predominância de um direito em detrimento dos demais porque essas categorias, como foi dito, apenas existem enquanto tipos ideais, isto é - como o destaca Weber-, abstrações teóricas parciais que, apesar de não existirem faticamente, iluminam a compreensão de uma dada realidade por poderem ser operacionalizadas do ponto de vista da pesquisa empírica. Assim, o que os autores colocam é que, independentemente da realidade em questão, esses três direitos coexistem de maneira mais ou menos harmônica, sendo a prevalência das características de um modelo sobre os demais o elemento que dará ao sistema jurídico em análise a sua feição mais ou menos próxima de cada tipo ideal.

Ao adotar uma perspectiva histórica, os autores desejam explicar, com sua tipologia evolucionista do direito, como e por que o sistema judicial norte-americano parecia vivenciar uma crise, já na metade dos anos 1960, no que diz respeito à sua capacidade de realizar a justiça social, em detrimento de apenas assegurar a liberdade individual. Assim, questões como qual deveria ser, em última instância, a função do direito em uma sociedade moderna e ainda qual deveria ser a relação entre o direito e a política emergem como indagações de particular importância no sentido de se alcançar uma melhor organização da vida coletiva por meio das instituições judiciárias. Nesse 
momento, inicia-se um intenso debate sobre as razões e os remédios para o aparente isolamento das instituições judiciais.

Em outros termos, a transição do direito autônomo para o direito responsivo e, consequentemente, a consolidação desse último modelo, aparecia como o grande desafio que a sociedade estaria impondo à Justiça dos Estados Unidos durante as décadas de 1960 e 1970. E a presença entre nós da tradução dessa obra de Nonet e Selznick justifica-se por ser esse, justamente, o desafio que a atual democracia brasileira impõe às instituições responsáveis pela administração da Justiça (categoria na qual se inclui não apenas o Judiciário, mas também as polícias), cobrando-Ihe maior abertura e consequencialismo em suas ações. Mas antes de destacar os riscos e desafios inerentes à passagem a um direito responsivo e suas implicações para o atual direito brasileiro, cumpre conhecer melhor a classificação dos autores, começando por aquele que eles consideram como o tipo mais rudimentar de sistema jurídico: o sistema jurídico repressivo.

O direito repressivo, característico de ordens políticas ainda em fase de consolidação, tem entre seus objetivos a uniformização social e a imposição de uma ordem almejada pela classe política, mais do que uma ordem consentida pelo conjunto da sociedade. Como consequência da permeabilidade entre as esferas do direito e da política no direito repressivo, os juízes e funcionários da Justiça são uma espécie de instrumento sem autonomia dos "donos do poder", que gozam de ampla possibilidade de desrespeito às normas jurídicas. Além disso, a manutenção da ordem a qualquer custo se torna a preocupação primordial das instituições de justiça e o direito penal aparece como o principal ramo do direito.

Num mesmo sentido, a "perspectiva oficial" torna a administração da Justiça um saber restrito e manipulável pelos funcionários do governo, algo que é garantido por barreiras de acesso às instituições responsáveis por essa atividade e pelo segredo na condução das operações dessas mesmas instituições. Por fim, o caráter moralizante e punitivo do direito instituiu a criminalização de determinadas parcelas da sociedade, esvaziando de sentido a expectativa de uma igualdade perante a lei.

Como são características fundamentais de todo sistema normativo a manutenção da ordem e o estabelecimento de certos padrões de conduta, assim como é essencial ao direito a possibilidade do recurso à coerção, o direito repressivo não deixa de ter certa proximidade com qualquer ordenamento jurídico. No entanto, o direito não é apenas o uso da força política para o cumprimento de normas, mas ainda, como destaca Alexy (2009), esse uso apoiado numa pretensão de correção. Ao fazer uso da terminologia de Habermas (1999), podemos dizer que o direito não se resume à sua faticidade, mas sim a combina com sua validade. E é nesse ponto que o direito repressivo mostra sua fraqueza, pois sua uniformização social por meio da força e sua permeabilidade à von- 
tade política reduzem sua dimensão de legitimação do poder político numa sociedade dotada de maior complexidade e diversificação.

Nesse sentido, um direito separado da política, capaz de instituir o governo das leis e não dos homens, surge como instituição que garantiria a esse tipo de sociedade uma ordem jurídica que ampliaria a dimensão de sua validade. Esse é o direito autônomo, que, como uma evolução do direito repressivo, busca sanar seu déficit de legitimidade. O "modelo de regras", de que o direito repressivo faz uso, torna-se o artifício por meio do qual busca alcançar tal fim. Afinal, esse modelo define claramente a diferença entre as obrigações políticas - formulação do conteúdo substantivo dessas regras - e judiciárias - aplicação de tais regras e suas consequências de acordo com procedimento predeterminado. Por um lado, a legitimidade é garantida quando essas regras oferecem um mecanismo aparentemente claro de responsabilidade pública: a sujeição das autoridades aos seus ditames expressos. Por outro, a ciência geral de que os juízes são limitados por essas regras leva à conclusão de que a discricionariedade de sua ação se estreita, tornando sua autoridade mais aceitável.

A pretensão à correção do sistema jurídico manifesta-se, assim, no direito autônomo pelo ideal de justiça liberal de um direito, ao contrário do que ocorre no modelo repressivo, cego às diferenças, subordinando todos - incluindo os governantes - a seu jugo ao mesmo tempo em que garante a todos que essa subordinação obedecerá ao devido processo legal ${ }^{5}$ e às normas de equidade. Nesse tipo de direito, o foco não é a constrição da vontade individual pela vontade coletiva, mas a forma como isso ocorre, o procedimento que se utiliza para viabilizar a administração dos conflitos sociais, independentemente do resultado atingido por essa administração.

Essa justiça, estritamente procedimental, no entanto, peca por ser incapaz de contrapor-se a casos de injustiças sociais substantivas e fortemente sedimentadas. $O$ direito autônomo, centrado em seus procedimentos e condicionado à estrita obediência às regras prescritas pelo Poder Legislativo, acaba se tornando insensível às demandas da sociedade e sua autonomia acaba degenerando em insulamento. Contra esses casos de injustiças socialmente sedimentadas, sua "cegueira" perante as diferenças sociais faz de seus procedimentos um meio inócuo de promoção de ideais de justiça substantiva. E se, por um lado, o direito repressivo, em sua sede de manutenção da ordem, foi pouco sensível à dimensão jurídica necessária de promoção da legitimidade, por outro, o direito autônomo, visando cobrir essa dívida do direito repressivo, acabou por negligenciar outra dimensão jurídica essencial: a promoção da justiça.

O ideal de equidade do direito autônomo permitiu que o acesso aos procedimentos e instituições judiciárias e às suas promessas de justiça fosse reclamado pelos mais diversos estratos sociais. No entanto, o que as parcelas desfavorecidas da sociedade
5. Cumpre destacar que a própria expressão "devido processo legal" traz em si o entendimento de que o processamento judicial é uma forma de proteger o indivíduo da tirania que a política pode incutir sobre ele, das arbitrariedades que, na atividade de administração de conflitos, os tribunais podem vir a realizar. Essa expressão engloba, portanto, uma série de determinações legais que têm como objetivo processar demandas diversas da sociedade, de maneira independente da vida política e de maneira a garantir a igualdade de todos os indivíduos sob o jugo de um dado ordenamento jurídico. 
demandavam ao direito autônomo era algo que seu ideal de justiça procedimental e obediência ao modelo de regras não podia dar-lhes: maior maleabilidade e capacidade de atendimento às demandas populares, que sua subordinação material ao poder legislativo não lhe permitia prover. Nesse contexto, surge o anseio de um novo tipo de direito, capaz de responder a essa demanda social por justiça substantiva. Trata-se do que Nonet e Selznick chamaram de direito responsivo.

Portanto, a passagem do direito autônomo ao direito responsivo implica, por um lado, sua abertura ao entorno social, considerada enquanto forma de autocorreção e, por outro lado, sua orientação para resultados, concebidos como forma de solução competente dos problemas que esse entorno traz às instituições judiciárias. Nessas circunstâncias, o modelo de regras é relativizado; a equidade não é mais cega e se vê ultrapassada pela competência; a formulação das regras e princípios de ação das instituições judiciárias é feita de baixo para cima; e a moralidade não é mais totalitária nem a desobediência tomada sempre como agressão ao sistema.

Na perspectiva do direito responsivo, as normas jurídicas são criadas de maneira negociada, sendo produto da vontade de cidadãos com elevado patamar de civilidade e, por isso, consciência de sua capacidade de influenciar na construção de políticas públicas a partir dos processos de criação de regras e de mecanismos alternativos para a solução de controvérsias. Nesse cenário, o direito é muito mais uma metodologia para a vocalização de preferências ou para a solução de conflitos do que propriamente um mecanismo autoritário ou estatal de estruturação da vida coletiva.

A responsividade é vista pelos autores como forma de evolução do direito, mas eles não deixam de destacar que se trata de uma evolução que põe em risco o próprio direito que, abrindo-se demais, pode perder sua integridade e, consequentemente, sua especificidade e utilidade. Trata-se, portanto, de uma das duas formas pelas quais o direito pode morrer. Um equilíbrio delicado entre abertura e fechamento caracteriza portanto o direito responsivo, que, se, por um lado, deve dispor de mecanismos de autocorreção, por outro, não pode, sob esses mesmos influxos, ser instrumentalizado por forças sociais e políticas específicas. O grande desafio do direito responsivo é, portanto, manter sua integridade sem cair no insulamento do direito autônomo, e abrir-se às demandas sociais sem cair na instrumentalização do direito repressivo.

Em um cenário como esse apresentado, o balanço entre integridade e abertura seria dado pela capacidade de os indivíduos fazerem com que suas preferências sejam incorporadas no direito, respeitando-se, por conseguinte, a integridade do próprio ordenamento enquanto sistema produtor de regras procedimentais para a administração do conflito. Nas palavras dos próprios autores: 
Os três sistemas de direito, repressivo, autônomo e responsivo, podem ser vistos como três respostas ao dilema entre integridade e abertura. A marca distintiva do direito repressivo é a adaptação passiva e oportunista das instituições judiciárias ao ambiente social e político. O direito autônomo é uma reação contra essa abertura indiscriminada e focaliza sobretudo a preservação da integridade institucional. Por isso o sistema se fecha em si mesmo, reduz sua responsabilidade com o ambiente social e aceita como preço da integridade o formalismo cego. O terceiro tipo busca resolver essa tensão. Preferimos denominá-lo de responsivo, em vez de aberto ou adaptável, para sugerir a capacidade de adaptação responsável, ou seja, discriminada e seletiva. Uma instituição responsiva conserva a capacidade de compreender o que é essencial à sua integridade ao mesmo tempo em que leva em consideração as novas forças do ambiente social. Para isso ela se baseia nas formas pelas quais a integridade e a abertura se sustentam mutuamente, mesmo quando conflitantes. Percebe as pressões sociais como fontes de conhecimento e de oportunidade de autocorreção. Para assumir essa postura, a instituição necessita contar com uma diretriz e uma finalidade. Os propósitos determinam padrões para crítica da prática estabelecida, e com isso indicam direções para a mudança. Ao mesmo tempo, se considerados positivamente, os fins permitem controlar a discricionariedade administrativa e diminuir o risco de capitulação das instituições (Nonet e Selznick, 2010: 125-126, grifos no original). ${ }^{6}$

Tendo em vista esse referencial teórico, após a apresentação do desempenho dos distritos policiais avaliados em Pernambuco, São Paulo e Rio de Janeiro nos anos de 2009 a 2011, no âmbito da "Semana de visitas a delegacias de polícia", os paradigmas do direito repressivo, autônomo e responsivo serão utilizados para a elaboração de um melhor entendimento sobre as transformações ocorridas em tais unidades. A ideia a ser explorada é a de que a necessidade da polícia de se tornar mais permeável e responsiva à população teve como efeito positivo o aumento da igualdade e da transparência na forma como os serviços policiais são prestados sem que isso, contudo, fosse capaz de eliminar o caráter eminentemente autoritário de algumas de suas práticas.

\section{A "Semana de visitas a delegacias de polícia"}

A "Semana de visitas a delegacias de polícia" é uma pesquisa-ação que tem por objetivo:

1. coletar informações sobre a qualidade do serviço oferecido pela polícia aos cidadãos;

2. permitir que os membros da comunidade atendida pelas delegacias de polícia conheçam tais unidades e os serviços que os policiais realizam em sua rotina diária;
6. Nesse ponto, fica explícito a especial atenção aos fins do direito responsivo, o que, no entanto, como também fica claro no trecho, não faz com que essa perspectiva do direito seja meramente ou mesmo primordialmente teleológica. Na verdade, há por parte dos autores uma preocupação muito grande com a manutenção de algumas conquistas do direito autônomo, de forma que preocupações deontológicas também ocupem posição central no direito responsivo. Nesse sentido, os autores parecem aproximar-se mais de Dworkin do que de pragmatistas que pregam o experimentalismo judicial. Mesmo assim, cumpre destacar que, apesar da proximidade, o direito como integridade, tal como concebido por Dworkin (2003), não encampa completamente o direito responsivo, sendo que até mesmo a integridade não significa a mesma coisa para Dworkin e para Nonet e Selznick - sendo possível conjecturar que enquanto a integridade de Nonet e Selznick tem seu auge no direito autônomo, a integridade buscada por Dworkin teria seu ápice no que Nonet e Selznick 
caracterizam como direito responsivo. Ademais, a longa nota 146 do livro demonstra como os autores questionam a distinção que Dworkin faz entre argumentos de princípio e argumentos de política e a pertinência de cada tipo na argumentação judicial.

7. Organização não governamental sediada em Nova York, hoje coordenadora geral do projeto.

8. O projeto era o

"Measuring progress toward safety and justice: a global guide to the design of performance indicators across the justice sector", que contou com a participação das organizações que, hoje, são fundadoras da Altus: Centro de Estudos de Segurança e Cidadania (Brasil); Centro de Estudos em Segurança Cidadã (Chile); Fundação Cleen (Nigéria); Instituto de Desenvolvimento e Comunicação (Índia); Fundação Indem (Rússia); Instituto de Justiça Vera (Estados Unidos da América). Para maiores informações, cf. <www.altus.org>.
3. oferecer a oportunidade de a polícia conhecer o que pensam os cidadãos sobre os serviços oferecidos pela delegacia e, com isso, desenvolver ações que visem a sua melhoria;

4. comparar a qualidade do serviço oferecido pelas polícias entre as distintas localidades de um mesmo país e entre os diferentes países;

5. aumentar a visibilidade das boas práticas desenvolvidas por delegacias de polícia que podem ser replicadas;

6. conceder um prêmio às unidades que se destacam por oferecer um serviço excepcional em seu país.

É, portanto, uma pesquisa global, realizada simultânea e anualmente em mais de 20 países com o objetivo de levar cidadãos, potenciais usuários dos serviços oferecidos por tais agências, a avaliarem o atendimento que estas prestam ao público e, ainda, reconhecer o serviço prestado pelas delegacias de polícia a partir da concessão do prêmio Altus.

Esse estudo foi concebido a partir do trabalho conjunto de seis organizações distintas, sob coordenação do Vera Institute of Justice, ${ }^{7}$ objetivando a criação de indicadores para o monitoramento e a avaliação do desempenho do sistema de justiça criminal. ${ }^{8} \mathrm{~A}$ partir desse estudo pioneiro, começou-se a desenhar a criação de uma aliança de centros de pesquisa que, contínua e permanentemente, empreendessem investigações com foco na avaliação da qualidade do serviço prestado pelas agências que compõem o sistema de justiça criminal. A decisão de enfatizar o tema da polícia está relacionada ao fato de essa constituir-se na primeira e decisiva instância do sistema de justiça criminal, o que torna imprescindível não apenas que a comunidade a conheça bem, mas que seja capaz de compreender seu papel e de confiar em sua atuação, procurando-a sempre que ocorrer um delito.

A proposta da Altus era, portanto, a construção de uma pesquisa-experimento, na qual os indivíduos fossem chamados a opinar sobre a qualidade do serviço prestado pelas delegacias de polícia. Contudo, as informações coletadas deveriam ser úteis para subsidiar as discussões relacionadas à reforma da polícia nos países-sede de tal aliança global. Para desenvolver esse instrumento, foi mobilizada uma equipe de pesquisadores de vários países, especialistas na área da polícia. Além disso, foram analisados os dispositivos de tratados internacionais sobre como as delegacias de polícia devem funcionar no sentido de garantirem um tratamento igualitário a todos indivíduos. A partir desse material, foram formuladas 20 perguntas básicas, agrupadas em cinco blocos temáticos (Quadro 2).

O formulário final desenvolvido pela Altus é composto por 20 questões quantitativas que devem ser respondidas de acordo com a escala likert, atribuindo-se valores entre 


\section{QUADRO 2}

Dimensões aVAliadas Pelo formulário da "Semana de VISitas a delegacias de polícia", DE ACORDO COM OS DIPLOMAS CONSULTADOS PARA A FORMULAÇÃO DE CADA QUESTÃO

\begin{tabular}{|c|c|c|}
\hline Dimensão & Itens avaliados & Documentos consultados \\
\hline $\begin{array}{l}\text { Orientação } \\
\text { para a } \\
\text { comunidade }\end{array}$ & $\begin{array}{l}\text { Localização da delegacia; } \\
\text { Espaço e facilidades destinadas a servir o público que } \\
\text { chega para registrar um crime ou solicitar informa- } \\
\text { ções; } \\
\text { Disponibilidade de informações sobre como reportar } \\
\text { um crime ou obter serviços públicos; } \\
\text { Staff alocado para servir o público ou registrar crimes. }\end{array}$ & $\begin{array}{l}\text { Declaração Universal dos Direitos Humanos; } \\
\text { Art. } 29 \text { do Código de Conduta; } \\
\text { Declaração das Nações Unidas sobre as Regras Mí- } \\
\text { nimas de Aplicação das Medidas não Privativas de } \\
\text { Liberdade (Regras de Tóquio). }\end{array}$ \\
\hline $\begin{array}{l}\text { Condições } \\
\text { materiais }\end{array}$ & $\begin{array}{l}\text { Grau de organização e limpeza da delegacia; } \\
\text { Condições físicas do prédio e da mobília; } \\
\text { Condições de trabalho para os próprios policiais; } \\
\text { Condições para as vítimas e testemunhas identifica- } \\
\text { rem suspeitos sem serem vistas. }\end{array}$ & $\begin{array}{l}\text { Declaração das Nações Unidas para a Eliminação de } \\
\text { todas as Formas de Discriminação Racial (Cerd); } \\
\text { Declaração das Nações Unidas sobre as Regras Mí- } \\
\text { nimas de Aplicação das Medidas não Privativas de } \\
\text { Liberdade (Regras de Tóquio); } \\
\text { Declaração dos Princípios Básicos de Justiça para as } \\
\text { Vítimas de Crime ou de Abuso de Poder (Declaração } \\
\text { das Vítimas). }\end{array}$ \\
\hline $\begin{array}{l}\text { Tratamento } \\
\text { igualitário }\end{array}$ & $\begin{array}{l}\text { Condições para as vítimas ou testemunhas de crime } \\
\text { registrarem o seu depoimento em casos em que a } \\
\text { privacidade é importante; } \\
\text { Facilidades e condições dos equipamentos disponí- } \\
\text { veis para servir às mulheres; } \\
\text { Condições de acesso à delegacia de polícia para pes- } \\
\text { soas com dificuldades de locomoção (idosos, pessoas } \\
\text { com lesões temporárias ou permanentes); } \\
\text { Serviços disponíveis especificamente para grupos } \\
\text { minoritários. }\end{array}$ & $\begin{array}{l}\text { Art. } 7 \text { da Declaração das Nações Unidas para a Elimi- } \\
\text { nação de todas as Formas de Discriminação Racial } \\
\text { (Cerd); } \\
\text { Convenção das Nações Unidas para a Proteção dos } \\
\text { Direitos Civis e Políticos (ICCPR); } \\
\text { Código de Conduta; } \\
\text { Declaração dos Princípios Básicos de Justiça para as } \\
\text { Vítimas de Crime ou de Abuso de Poder (Declaração } \\
\text { das Vítimas); } \\
\text { Convenção das Nações Unidas para a Eliminação de } \\
\text { qualquer Forma de Discriminação contra as Mulhe- } \\
\text { res. }\end{array}$ \\
\hline $\begin{array}{l}\text { Transparência } \\
\text { e prestação } \\
\text { de contas }\end{array}$ & $\begin{array}{l}\text { Informações disponíveis ao público sobre tendências } \\
\text { de crime na área atendida pela delegacia; } \\
\text { Informações disponíveis ao público sobre o desempe- } \\
\text { nho da delegacia; } \\
\text { Informações disponíveis sobre como registrar uma } \\
\text { queixa em relação ao serviço prestado ou registrar } \\
\text { uma reclamação por desvio de conduta do policial; } \\
\text { Formas de identificação do staff da delegacia. }\end{array}$ & $\begin{array}{l}\text { Convenção das Nações Unidas para a Proteção dos } \\
\text { Direitos Civis e Políticos (ICCPR). }\end{array}$ \\
\hline $\begin{array}{l}\text { Condições de } \\
\text { detenção }\end{array}$ & $\begin{array}{l}\text { Condições de segurança da área de detenção; } \\
\text { Identificação dos detentos; } \\
\text { Condições das facilidades destinadas aos presos para } \\
\text { recebimento de advogados e familiares; } \\
\text { Condições sanitárias da área de detenção. }\end{array}$ & $\begin{array}{l}\text { Art. } 10 \text { da Declaração das Nações Unidas para a Pro- } \\
\text { teção de todas as Pessoas contra o Desaparecimento } \\
\text { Forçado; } \\
\text { Convenção das Nações Unidas para a Proteção de } \\
\text { todas as Pessoas sob Detenção ou qualquer forma } \\
\text { de Prisão; } \\
\text { Convenção das Nações Unidas para a Proteção dos } \\
\text { Direitos Civis e Políticos (ICCPR); } \\
\text { Declaração Universal dos Direitos Humanos. }\end{array}$ \\
\hline
\end{tabular}

Fonte: Altus (2012).

um (totalmente inadequado) e cinco (excelente) a cada um dos itens observados. Há, ainda, dez questões de livre resposta (abertas) que se destinam a qualificar as notas dadas aos itens anteriores, permitindo o registro de informações detalhadas sobre as impressões dos visitantes. As respostas às questões quantitativas são transformadas em uma escala cujo intervalo varia entre 20 e 100. Esses pontos permitem o cálculo da média final que, por sua vez, corresponde a um conceito em termos de qualidade 
do atendimento prestado por cada delegacia. A relação entre pontuação e significado da avaliação deve ser interpretada da seguinte forma (Tabela 1):

9. Exceção ao ano de 2008, no qual a pesquisa não pôde ser realizada, em razão da ausência de orçamento que custeasse essa atividade.

\section{O governo} do estado de Pernambuco tem, desde o ano de 2007, como Plano Estadual de Segurança Pública o Pacto pela Vida.

Este plano tem seis linhas de ação: repressão qualificada da violência; aperfeiçoamento institucional; informação e gestão do conhecimento; formação e capacitação; prevenção social do crime e da violência; e, por fim, gestão democrática. Pode-se dizer que os projetos desenvolvidos no âmbito do Pacto pela Vida, especificamente na polícia civil - seja na linha de ação repressão qualificada, ou da prevenção social do crime e da violência - priorizam as seguintes características: prevenção, mediação de conflitos, serviço social ao público e participação. Para alcance dos propósitos mencionados, a polícia civil, pela ação de boa parte de suas delegacias de polícia, tem desenvolvido alguns projetos que visam à aproximação da polícia com a comunidade.
TABELA 1

INTERVALOS DE PONTUAÇÃO PARA CLASSIFICAÇÃO DA QUALIDADE DO ATENDIMENTO PRESTADO PELAS DELEGACIAS DE POLÍCIA, DE ACORDO COM A METODOLOGIA DESENVOLVIDA PELA ALTUS

\begin{tabular}{|l|l|}
\hline Intervalo de pontos & Qualidade do atendimento prestado pela delegacia de polícia \\
\hline $20-35$ pontos & Totalmente inadequado \\
\hline $36-51$ pontos & Inadequado \\
\hline $52-67$ pontos & Adequado \\
\hline $68-84$ pontos & Mais do que adequado \\
\hline $85-100$ pontos & Excelente \\
\hline Fonte: Altus (2012). & \\
\hline
\end{tabular}

Finalizado o processo de confecção do instrumento, foi realizado um teste preliminar em oito países. Os resultados obtidos demonstraram que a ferramenta era, de fato, capaz de alcançar os objetivos propostos - de avaliação da qualidade do serviço prestado pelas delegacias de polícia e de aproximação entre essa agência e a comunidade por ela servida. Com isso, o questionário foi disponibilizado no site das organizações que participaram do projeto e no site da Altus.

No ano de 2004, o então governador do Ceará encontrou o questionário e manifestou o desejo de utilizá-lo para avaliar as delegacias da capital de seu estado, Fortaleza. O mesmo ocorreu com o Departamento de Segurança Pública da África do Sul. Percebendo o interesse despertado pela ferramenta, a Altus decidiu partir para uma nova etapa do projeto: transformar a utilização do formulário em um acontecimento global que congregasse, simultaneamente, instituições de pesquisa e cidadãos. Assim, surgiu a "Semana de visitas a delegacias de polícia", que vem sendo realizada anualmente desde o ano de 2006 em distintos países, incluindo o Brasil (Figura 1). ${ }^{9}$ Inicialmente, esta atividade acontecia sob os auspícios de um conjunto de financiadores, mas, desde 2009, a "Semana de visitas" é financiada pelo Department for International Development (DFID), do governo britânico.

Neste trabalho, estaremos analisando os dados resultantes de três anos (2009, 2010, 2011) de visitas sucessivas às mesmas delegacias de Recife (21 delegacias), São Paulo (22 delegacias) e Rio de Janeiro (21 delegacias). Essas cidades foram escolhidas por terem empreendido ações que tinham por objetivo a melhoria do serviço policial: Recife porque, no âmbito do "Pacto pela vida", ${ }^{10}$ tinha intentado uma série de reformas na polícia civil com vistas à melhoraria da estrutura física de suas unidades de atendimento, objetivando diminuir a resistência da população; Rio de Janeiro por ter sido 
FIGURA 1

SUMÁRIO DA QUANTIDADE DE PAÍSES E DE DELEGACIAS VISITADAS

a CADA ANO PELA "SEMANA DE VISITAS"

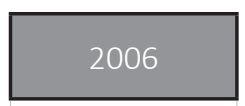

Primeira

semana de

visitas

471 delegacias visitadas em

23 países

109 delegacias visitadas no

Brasil

Fonte: Altus (2012).

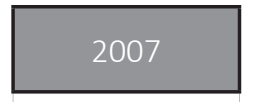

Segunda semana de visitas

832 delegacias visitadas em 22 países

158 delegacias visitadas no Brasil

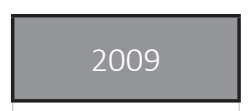

Terceira semana de visitas

1051 delegacias visitadas em 20 países

235 delegacias visitadas no Brasil

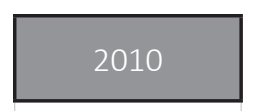

$\begin{aligned} & \text { Quarta } \\ & \text { semana de } \\ & \text { visitas }\end{aligned}$
1104 delega-
cias visitadas
em 22 países
172 delegacias
visitadas no
Brasil

2011

$\begin{aligned} & \text { Quinta } \\ & \text { semana de } \\ & \text { visitas }\end{aligned}$
1044 delega-
cias visitadas
em 20 países
64 delegacias
visitadas no
Brasil

o primeiro estado a conceber um projeto de modernização da polícia civil, que foi o Programa Delegacia Legal, exportado para diversos outros estados da Federação; São Paulo por ter sido a localidade com a mais importante diminuição de homicídios dolosos na última década e por atribuir essa mudança, em parte, à melhoria da qualidade do trabalho da polícia civil.

No que se refere à determinação do quantitativo de delegacias a ser visitado, desde o início o projeto pretendida viabilizar a visita a 20 delegacias distritais/seccionais (as chamadas "delegacias de bairro") localizadas nas capitais e regiões metropolitanas e ainda uma delegacia especializada no atendimento à mulher (Deam). Este quantitativo foi estabelecido levando-se em consideração a informação repassada pela Diretoria de Estudos e Pesquisas da Secretaria Nacional de Segurança Pública do Ministério da Justiça, que informava que cada capital/região metropolitana possuía, em média, 20 delegacias distritais (Altus, 2011).

Uma vez estabelecido o quantitativo de delegacias a serem visitadas em cada localidade, passou-se à escolha destas. Em Recife, o quantitativo é exatamente o número de delegacias existentes na Região Metropolitana e, por isso, não foi necessário qualquer procedimento de amostragem. Em São Paulo e no Rio de Janeiro, as delegacias visitadas foram sorteadas a partir da listagem das delegacias distritais/seccionais de cada região metropolitana. Cada delegacia recebeu um número aleatório e, após a ordenação de todas as unidades de maneira crescente, as 20 primeiras foram consideradas como elementos integrantes do conjunto principal de delegacias que seriam visitadas pela Altus e as demais foram descartadas (ou não inseridas na amostra). Pelo fato de cada capital dispor, em regra, de apenas uma Deam, todas essas delegacias especializadas foram automaticamente incluídas na amostra. 
11. Nesse caso, a Deam que compunha a amostra original foi substituída por outra Deam da cidade, já que a anterior estava em reforma e, por isso, fechada para o atendimento ao público.
Após todo esse procedimento, decidiu-se incluir uma delegacia adicional em São Paulo, por se tratar de um estabelecimento que havia sido construído de maneira modelar e, por isso, poderia indicar questões interessantes em termos de potencialidade da associação entre polícia e comunidade para a melhoria do serviço policial.

Portanto, as 64 delegacias analisadas neste estudo foram amostradas aleatoriamente em 2009, e acompanhadas nos anos seguintes com o objetivo de se verificar a possibilidade de transformação da qualidade do atendimento prestado à população. Isso significa que as delegacias visitadas em 2011, com a exceção da Deam de Recife, ${ }^{11}$ são exatamente as mesmas unidades de polícia civil que foram visitadas nos anos de 2009 e 2010, nas cidades do Rio de Janeiro, Recife e São Paulo, o que permite uma discussão detalhada das transformações verificadas nestas três localidades ao longo dos três anos de pesquisa.

Uma vez estabelecidas as delegacias a serem visitadas, foram formados grupos de visitantes com quatro pessoas: um coordenador da visita (estudante de ciências sociais) e três visitantes (pessoas que residem na área atendida pela delegacia de polícia). Nos últimos anos, alguns grupos contaram com visitantes fixos, isto é, pessoas que todos os anos visitam exatamente as mesmas delegacias com o objetivo de auxiliar na construção de uma espécie de desenho longitudinal da qualidade do serviço prestado.

Após a composição do grupo, o mesmo se reúne para um treinamento no qual ocorre a revisão de todas as questões do formulário padrão. A ideia é garantir que todos os participantes estejam cientes das dimensões a serem observadas na rotina da delegacia, já que não é permitido manejar o formulário e /ou tomar notas durante a visita. A visita tem duração de uma hora e meia, durante a qual os indivíduos devem conhecer a rotina da delegacia e, se possível, tirar fotos que permitam ilustrar a percepção de pontos negativos e/ou positivos da unidade policial. Ao final, os visitantes se reúnem para preencher o formulário e, em seguida, o coordenador da visita insere as avaliações (quantitativas e qualitativas) na matriz da Altus, viabilizando o cálculo das médias e, por conseguinte, a verificação da qualidade do atendimento prestado pela delegacia em questão.

Uma vez processados os resultados, são organizados workshops regionais para apresentação dos resultados, os quais contam não apenas com a equipe de coordenação da pesquisa, mas também com a chefia da polícia civil e os delegados responsáveis pelas unidades visitadas. Nesse momento, cada qual recebe um informativo com as notas da unidade de sua responsabilidade. Em seguida, são discutidas as principais políticas que podem ser implementadas com o objetivo de se melhorar a qualidade do atendimento prestado pelas delegacias de polícia. Ao final deste evento, os delegados 
devem preencher um formulário de avaliação da "Semana de visitas", apontando as suas potencialidades e os limites enquanto pesquisa-ação que tem por objetivo viabilizar determinados processos de reforma no âmbito da polícia.

De maneira esquemática, as fases da "Semana de visitas a delegacias de polícia" podem ser sumarizadas tal como apresentadas na Figura 2.

No ano de 2011, a partir do emprego desta metodologia, foi possível constatar que, em geral, as delegacias de polícia das cidades de Recife, Rio de Janeiro e São Paulo foram avaliadas como "adequadas" (60 pontos em média). As delegacias visitadas no Brasil ficaram em situação melhor que as bolivianas, argentinas e peruanas e em situação pior que as do México, Chile e dos Estados Unidos, tal como denota a Tabela 2.
FIGURA 2

ETAPAS ENVOLVIDAS NA ORGANIZAÇÃO DA Semana de Visitas a Delegacias de Polícia
Contato com a direção da polícia civil

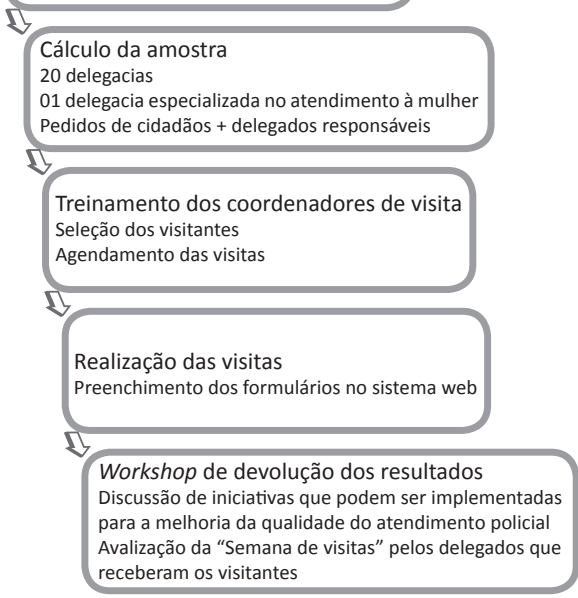

TABELA 2

PONTUAÇÃO RECEBIDA PELAS DELEGACIAS DE POLÍCIA NAS AMÉRICAS V "SEMANA DE VISITAS A DELEGACIAS DE POLÍCIA", 2011

\begin{tabular}{|c|c|c|c|c|c|c|}
\hline Localidade & 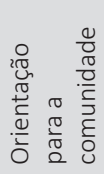 & 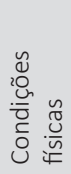 & 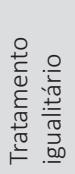 & 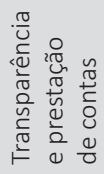 & 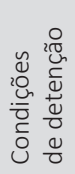 & $\begin{array}{l}\frac{*}{\pi} \\
\frac{\pi}{2} \\
00 \\
. \frac{0}{0} \\
\frac{0}{2}\end{array}$ \\
\hline Bolívia & 51 & 46 & 38 & 48 & 34 & 43 \\
\hline Argentina & 54 & 55 & 48 & 36 & 40 & 47 \\
\hline Peru & 61 & 57 & 53 & 58 & 50 & 56 \\
\hline Brasil & 68 & 68 & 59 & 51 & 53 & 60 \\
\hline México & 66 & 69 & 56 & 56 & 75 & 63 \\
\hline Chile & 75 & 74 & 69 & 71 & 69 & 72 \\
\hline Estados Unidos & 77 & 77 & 75 & 73 & 80 & 76 \\
\hline Global & 70 & 64 & 58 & 65 & 61 & 64 \\
\hline
\end{tabular}

* Não leva em consideração a média do item "condições de detenção", já que a maioria das delegacias visitadas nos países das Américas (com exceção do Brasil) não tem carceragem. Por isso, a média final apresentada é levemente mais elevada do que aquela do caso brasileiro, que será apresentada adiante, já que essa leva em consideração o item "condições de detenção". 
Tal como as demais delegacias latino-americanas representadas na pesquisa, é possível verificar que as unidades brasileiras apresentaram uma avaliação relativamente positiva nas áreas "orientação para a comunidade" e "condições físicas" e tiveram avaliações substantivamente negativas nos itens "transparência e prestação de contas" e "condições de detenção". Contudo, em que pese a avaliação positiva dos quesitos mencionados, o "destaque" fica com os valores atribuídos às delegacias chilenas, que apresentam uma avaliação bem superior às brasileiras em todos os quesitos considerados.

No que se refere à avaliação das delegacias brasileiras que participaram da V "Semana de visitas", a média geral é de 59 pontos, o que qualifica o serviço por elas prestado como adequado. Ao considerar apenas essa média global, é possível afirmar que a cidade do Rio de Janeiro possui delegacias com médias inferiores à nacional (58 pontos), enquanto Recife é a localidade com médias superiores a nacional (61 pontos). Já as delegacias de São Paulo apresentam pontuação média exatamente igual à média nacional (59 pontos). Quando os quesitos são analisados separadamente, percebe-se que as delegacias visitadas são bastante semelhantes em termos de orientação para a comunidade (já que as notas recebidas nesses critérios são quase as mesmas) e bastante distintas em termos de tratamento igualitário da população, já que existe uma certa variação entre as notas recebidas nesse critério (Tabela 3).

\section{TABELA 3}

MÉdiA DOS PONTOS RECEBIDOS PELAS DELEGACIAS DE POLÍCIA AVALIADAS NO BRASIL, POR CRITÉRIO DE CIDADE. V "SEMANA DE VISITAS A DELEGACIAS DE POLÍCIA", 2011

\begin{tabular}{|c|c|c|c|c|c|c|}
\hline Localidade & 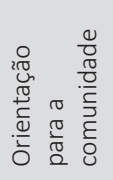 & 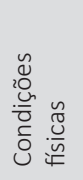 & 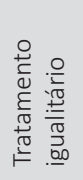 & 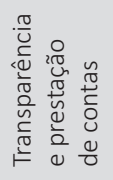 & 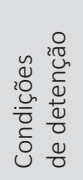 & $\begin{array}{l}\frac{*}{0} \\
\frac{0}{2} \\
00 \\
. \frac{\pi}{0} \\
\frac{\mathscr{U}}{\Sigma}\end{array}$ \\
\hline Recife & 68 & 66 & 56 & 54 & 53 & 61 \\
\hline Rio de Janeiro & 66 & 66 & 59 & 49 & 51 & 58 \\
\hline São Paulo & 68 & 71 & 61 & 50 & 56 & 59 \\
\hline Brasil & 68 & 68 & 59 & 51 & 53 & 59 \\
\hline
\end{tabular}

* Neste caso, a média final inclui os valores da área de detenção e, por isso, é menor do que aquele apresentado na Tabela 2.

Algumas questões merecem destaque quando se observa a Tabela 3. Primeiro, o fato de as delegacias das três localidades não se diferenciarem muito em termos da pontuação verificada no item "orientação para a comunidade", sendo que as delegacias do Rio de Janeiro alcançaram média equivalente à "adequada", enquanto as das demais cidades alcançaram a excelência. No quesito "condições físicas", as diferenças são maiores, já que as delegacias de São Paulo alcançaram a nota "excelente", mas as do Rio de Janeiro e do Recife ficaram com avaliação "adequada". 
Em termos de "tratamento igualitário" da população, as delegacias das três cidades receberam notas equivalentes à "adequada". Contudo, o mesmo não ocorreu quando o critério considerado foi o de "transparência e prestação de contas". No último caso, apenas as delegacias do Recife alcançaram avaliação "adequada". Por fim, cumpre destacar que no quesito "condições de detenção" apenas as delegacias do Rio de Janeiro foram avaliadas como "inadequadas", sendo as demais classificadas como "adequadas".

Mesmo considerando que as delegacias das três cidades que participaram da V "Semana de visitas" foram classificadas como adequadas, os problemas encontrados no Rio de Janeiro, especialmente em termos de "transparência e prestação de contas" e "condições de detenção" parecem ser maiores que os observados nas demais localidades. Interessante notar que, em princípio, esse não era o resultado esperado. Afinal, essa foi a primeira cidade a desenvolver projetos de reforma da polícia civil, em fins da década de 1990. No âmbito de tal reforma, criou-se o Programa Delegacia Legal que tinha como premissa a utilização da carceragem de maneira apenas eventual e não continuada. Além disso, no bojo desse processo foi criada a Ouvidoria de Polícia que deveria, entre outras funções, zelar pela transparência e prestação de contas do conjunto das unidades policiais. ${ }^{12}$ Em razão da existência desses dois projetos, era de se esperar que o Rio de Janeiro tivesse um desempenho substantivamente superior em termos de transparência e prestação de contas e condições de detenção, o que não se verifica.

Quando os resultados alcançados pela V "Semana de visitas a delegacias de polícia" são comparados com aqueles obtidos nos dois anos anteriores, é possível perceber (Gráfico 1):

1. em São Paulo são verificadas melhorias ao longo dos três anos considerados, sendo as mais substanciais aquelas processadas na passagem de 2009 para 2010;

2. em Recife houve grande melhoria do primeiro para o segundo ano do projeto, com estabilização do segundo para o terceiro ano;

3. no Rio de Janeiro ocorreu melhoria substantiva entre os dois anos extremos da série, mas houve pequena piora entre os anos de 2009 e 2010.

A questão parece ser, portanto, como explicar a mudança na pontuação média que sumariza a qualidade do atendimento prestado pelas delegacias de polícia nestas três localidades. Afinal, especialmente nos casos de Recife e de São Paulo, as unidades deixaram de ser classificadas como inadequadas para alcançarem a qualificação de adequadas.

Como a proposta deste artigo é problematizar como a passagem para o direito responsivo tem ocorrido no âmbito das delegacias de polícia visitadas pelo projeto, a
12. Para maiores informações sobre esses projetos, cf. Soares (2000). 
13. A reflexão oriunda das transformações vivenciadas pelo sistema de justiça criminal nas últimas décadas é importante quando se pretende discutir o padrão de operação das delegacias de polícia porque este é entendido como a concatenação da (i) polícia civil - que registra os crimes inicialmente e procura apontar um suspeito para essa ocorrência; com o (ii) Ministério Público - que acusa publicamente o suspeito apontado pela polícia; e o (iii) Judiciário que, a partir da argumentação produzida pelo Ministério Público e pela Defensoria Pública (ou privada), e a partir das provas produzidas pela polícia e (re) produzidas nas audiências judiciais, condena ou absolve o suspeito. Logo, qualquer movimento de transformação no âmbito das organizações mencionadas refletese em alterações nas que a ela estão concatenadas.
GRÁFICO 1

Comparativo dA PONTUAÇÃO GLOBAL DAS DELEGACIAS DE RECIFE, RIO DE JANEIRO E SÃO PAULO QUE PARTICIPARAM DAS TRÊS EDIÇÕES DO PROJeto III, IV E V “SEMANA de VISITAS A DElegacias de PolíciA" (2009 A 2011)

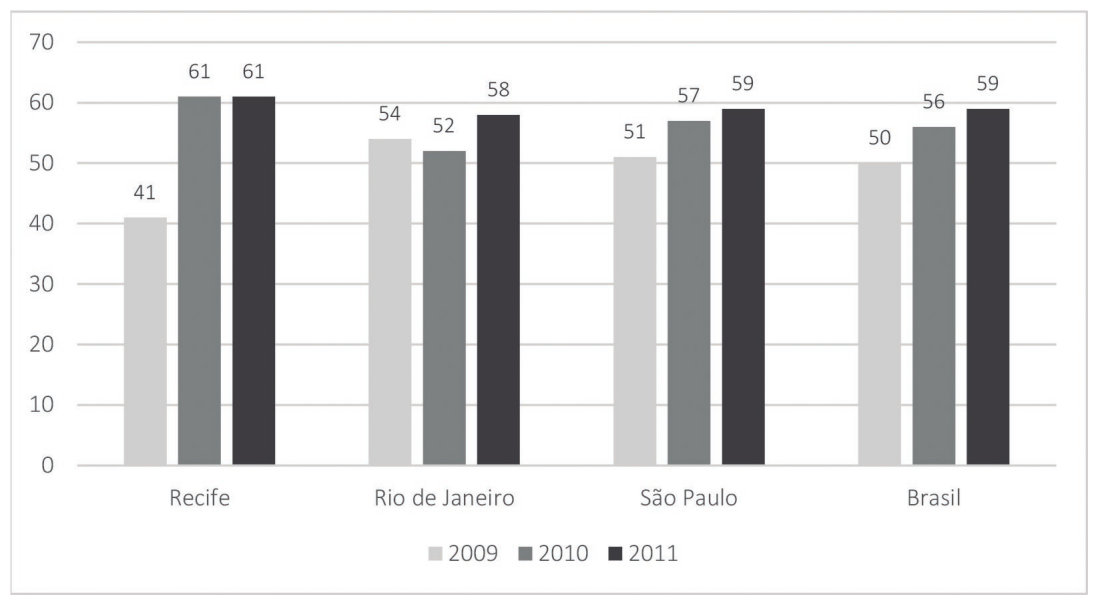

seção seguinte procura apontar como a melhoria na qualidade do atendimento prestado pela polícia ao cidadão é decorrente do progressivo entendimento dos policiais de que eles são prestadores de um serviço público essencial e que, por isso, devem fazê-lo sem distinção de gênero, sexo, idade e, ainda, com absoluta transparência e respeito aos direitos humanos, incluindo o direito dos detidos. Para essa finalidade, foram utilizadas as informações extraídas dos questionários de avaliação dos workshops de devolução e discussão dos resultados da "Semana de visitas".

\section{Percepções dos indivíduos e dos delegados: será que a polícia civil brasileira está mesmo caminhando para o direito responsivo?}

A discussão sobre os processos de reforma da polícia civil se insere no âmbito da reflexão sobre a necessidade de se transformar os padrões de operação do sistema de justiça criminal, no qual a organização policial é a porta de entrada. No Brasil, a questão da reforma das organizações do sistema de justiça criminal ${ }^{13}$ passa a se conformar em objeto de discussões acadêmicas e de políticas públicas estaduais e federais a partir do final da década de 1990, quando se constata a institucionalização daquilo que Peralva (2001) denominou como o paradoxo brasileiro: a explosão da violência vis-à-vis a consolidação da democracia procedimental.

Neste cenário, para que a democracia pudesse se institucionalizar do ponto de vista substantivo fazia-se necessário alterar os padrões de operação das organizações que 
compunham o sistema de justiça criminal em geral, e das polícias em especial, as quais possuíam práticas dissonantes da própria ideia de democracia, tal como o uso de sua discricionariedade para efetuar prisões ilegais, eliminar bandidos sem o devido processo legal ou, ainda, uso da tortura para encerrar investigações policiais de maneira bem sucedida (Misse, 2010).

Desde o trabalho seminal de Paixão (1982) sobre o funcionamento das delegacias de polícia na Região Metropolitana de Belo Horizonte, os estudos sobre padrões de funcionamento das organizações policiais reforçam a dualidade em termos de princípios vigentes no cotidiano das delegacias de polícia. Nelas convivem, de um lado, a formalidade legal, que as situa como importante instrumento de implementação da lei na qualidade de polícia judiciária e, de outro lado, a informalidade das negociações que ocorrem com o objetivo de impedir que o indivíduo registre um crime, o que faz com que o poder de polícia seja o de decidir sobre o que será ou não encaminhado à apreciação do Ministério Público e do Judiciário. ${ }^{14}$

Nesses termos, ao revisar os estudos já realizados sobre os processos de reforma que ocorreram desde a reabertura democrática (1985) até os anos mais recentes (2010), Sinhoretto (2011: 96) classifica-os em dois grupos distintos:

1. os que enfatizam os obstáculos à democracia e à incorporação da cultura jurídica de demandas e valores democratizantes, analisando a persistência de valores e práticas hierarquizantes e excludente;

2. os que valorizam a ruptura e a mudança diante da reorientação das identidades corporativas e da emergência de práticas inovadoras de transformação na cultura jurídica do país.

Ao tomar por referência a passagem do paradigma do direito repressivo ao direito responsivo - na obra de Nonet e Selznick -, e aplicando-a às delegacias de polícia, o esperado seria uma transformação da situação 1 em direção à situação 2. Com isso, os serviços policiais deixariam de ter como foco a manutenção da ordem, especialmente aquela que decorre do uso de mecanismos como tortura e letalidade, para uma focalização nos problemas dos cidadãos e, por conseguinte, na prestação de um serviço que viabilizasse, pelo menos, a adequada administração do conflito. Contudo, o que se verifica, na realidade das delegacias de polícia, é a convivência entre esses dois opostos.

Nesse sentido, os dados extraídos dos formulários de avaliação da "Semana de visitas" - preenchidos por alguns dos policiais ${ }^{15}$ que participaram dos workshops de devolução de resultados em maio e junho de 2012 - podem indicar como essas duas dimensões, em tese opostas, têm se combinado nas delegacias das cidades de Recife, Rio de
14. Poucos são os estudos que focalizam essa dimensão do trabalho policial no Brasil. Para uma discussão de como isso ocorre em localidades como as dos Estados Unidos da América, cf. "Justice without trial", de Jerome Skolnick.

15. Em algumas localidades, como foi o caso de Recife, alguns policiais (oito) tiveram uma emergência e, por isso, saíram antes do encerramento do workshop, não vindo a preenchê-lo Da mesma forma, cinco policiais não conseguiram participar no Rio de Janeiro e dois em São Paulo, o que fez com que do total de 64 policiais que receberam visitantes, apenas 49 preenchessem o questionário de avaliação, sendo esse o resultado que será apresentado. 
Janeiro e São Paulo nos últimos anos. O que se pretende problematizar com os relatos dos policiais é se a melhoria na qualidade do atendimento prestado pelas delegacias de polícia pode ser considerada como tentativa de a organização policial passar de um processo de gestão de conflitos baseado na ideia de direito repressivo - assentado em estruturas legais mais autoritárias e em uma cultura de uso arbitrário do poder de polícia - para um processo de gestão de conflitos baseado na ideia de direito responsivo, posto que mais preocupado com as demandas dos próprios indivíduos.

TABELA 4

NÚMERO DE DELEGADOS QUE RESPONDERAM POSITIVAMENTE ÀS QUESTÕES SOBRE CONHECIMENTO DOS OBJETIVOS DO PROJETO E PARTICIPAÇÃO ANTERIOR NO WORKSHOP DE DEVOLUÇÃO DE RESULTADOS. WORKSHOP DA V “SEMANA DE VISITAS A DELEGACIAS DE POLÍCIA”, 2012

\begin{tabular}{|c|c|c|c|}
\hline Cidade & N & $\begin{array}{c}\text { N conhece a } \\
\text { Semana de Visitas }\end{array}$ & $\begin{array}{c}\text { N já tinha } \\
\text { participado do workshop }\end{array}$ \\
\hline Recife & 13 & 10 & 9 \\
\hline Rio de Janeiro & 16 & 9 & 9 \\
\hline São Paulo & 20 & 11 & 25 \\
\hline Total & 49 & 30 & 7 \\
\hline
\end{tabular}

De acordo com essas avaliações, a maioria dos delegados disse ter conhecimento do significado da "Semana de visitas a delegacias de polícia" (Tabela 4, acima) e, quando indagados sobre este, apontaram como objetivos da pesquisa-ação:

1.o desenvolvimento de uma metodologia de avaliação da qualidade do atendimento prestado pelas delegacias de polícia operacionalizada pelos próprios cidadãos;

2. a aproximação entre a polícia e os seus usuários, a partir da adequação do serviço oferecido à demanda dos cidadãos;

3. a constituição de um mecanismo de controle civil da atividade policial, dada a ênfase na dimensão de "fiscalização" que este projeto teria, tal como denotam as citações a seguir.

"É uma avaliação de como estão as delegacias, de que maneira ajudam a população e o que pode ser feito para melhorar o atendimento ao usuário" (delegado do Rio de Janeiro).

"É uma ação que visa colher elementos para melhorar sua forma de 'ser' e conformá-la de acordo com o que gostaria o cidadão" (delegado do Rio de Janeiro).

"De forma objetiva, trata-se de uma avaliação - conduzida pela sociedade civil - da atividade da desenvolvida pelo policial civil, ofere- 
cendo ao avaliado a real dimensão de como a população vê o serviço prestado" (delegado de Recife).

“É uma avaliação feita por cidadãos que exerce função crítica no intuito de transpassar aos avaliados quais aspectos são merecedores de continuarem tal como estão e quais aspectos demandam melhorias à sociedade, vista de uma forma ampla" (delegado de Recife).

"É uma semana de integração entre os visitantes, os funcionários e uma pequena parte da população, que necessita de auxílio policial ou não" (delegado de São Paulo).

"Tem como objetivo avaliar o desempenho das atividades e o atendimento ao público como fatos relacionados a segurança pública" (delegado de São Paulo).

De certa maneira, o entendimento que os delegados de polícia atestam acerca dos objetivos da "Semana de visitas" parece indicar que, em razão desta, eles passaram a se preocupar um pouco mais com a satisfação do usuário pelo serviço prestado (o que está mais relacionado à dimensão responsiva) para além das atividades tradicionais da polícia de manutenção da ordem ou aplicação dos procedimentos tipicamente judiciais (o que está mais relacionado à dimensão repressiva). Afinal, uma das questões apontada por quase todos os policiais que responderam ao formulário foi a relativa à avaliação da ação policial pelos cidadãos que a pesquisa engendra, fazendo com que a delegacia passasse a se preocupar também com as demandas daqueles que a procuram para além da manutenção da ordem e realização dos objetivos da polícia judiciária.

Com o objetivo de desvelar em que medida essa associação entre os propósitos da "Semana de visitas" e as mudanças empreendidas nas delegacias de polícia nos itens avaliados pelo formulário da Altus de fato possuíam uma relação de causa e efeito, as perguntas seguintes do formulário mensuravam a participação prévia do policial no workshop de devolução de resultados e, ainda, o significado deste evento para o participante. Os resultados indicam que, aproximadamente, metade dos policiais que responderam à avaliação já tinha participado do workshop de devolução de resultados da "Semana de visitas" (Tabela 4, acima).

No que diz respeito ao papel cumprido pelos workshops de devolução de resultados em termos de alterações na prática cotidiana da delegacia de polícia, os entrevistados enfatizaram que este evento ajuda-os a melhor conhecer o que ocorre na unidade e, dessa forma, adequar os seus serviços às demandas dos cidadãos, tal como indicam as citações a seguir:

"Auxilia a identificar as dificuldades ou falhas identificadas pela avaliação, o que possibilita, através do conhecimento, levar empenho para solução ou melhoria" (delegado do Rio de Janeiro). 
“Permitem pontuar que atividades e situações são caras à sociedade que esta aponta como essenciais ao bom trabalho policial" (delegado do Rio de Janeiro).

"Através dos dados coletados e publicados, pode haver modificações na delegacia, bem como a inserção de novos sistemas de trabalho e divulgação de informações" (delegada de Recife).

"Através do aprimoramento dos mecanismos de atendimento prestado pelas delegacias, a população que necessita de serviços com agilidade, eficiência e resultados positivos será beneficiada" (delegado de Recife).

"Acho que pode melhorar muito e direcionar um procedimento adequado à população" (delegado de São Paulo).

"A devolução causa impacto, pois desperta o interesse de adequar melhor $\mathrm{o}$ atendimento ao público, com a qualidade de suprir falhas observadas" (delegado de São Paulo).

Mas, se essa é a percepção dos policiais, em que medida os cidadãos que necessitam dos serviços das delegacias manifestam entendimento similar em relação a essa adequação entre o serviço policial oferecido pela unidade e suas demandas? Será que o usuário das delegacias de polícia de Recife, São Paulo e Rio de Janeiro tem percebido esse processo de alteração do paradigma de operação policial, que estaria saindo do direito repressivo para o direito responsivo?

Para responder a essas duas indagações serão utilizadas duas questões constantes da parte qualitativa do formulário de avaliação das delegacias de polícia, quais sejam:

1. O que significou para vocês ser parte do grupo da "Semana de visitas a delegacias de polícia?", e

2. Se você participou das edições anteriores da "Semana de visitas", vindo a essa mesma delegacia de polícia, por favor, descreva como as práticas policiais, o relacionamento com a comunidade e os serviços propiciados pela delegacia mudaram.

Para vários visitantes, a decisão em participar na "Semana de visitas" é resultado da curiosidade em compreender como funciona uma delegacia de polícia. Para muitos, especialmente os que nunca estiveram em um distrito policial, este é um local inóspito e que deve ser evitado a todo o custo. Por isso, a pesquisa-ação seria uma oportunidade de conhecer esse ambiente que, de outra forma, permaneceria apenas temido.

P., 21 anos, estudante: "Achei que era uma oportunidade de conhecer uma delegacia pelos meus olhos, e não unicamente sobre o que as pessoas falavam a respeito. Foi legal para quebrar preconceitos". 
I., 29 anos, promotora de vendas: "Vim por curiosidade, quando você me falou em avaliar os serviços prestados por uma delegacia, pensei logo em avaliar somente as coisas ruins que ia encontrar e me surpreendi".

Para outros, a participação se deve ao interesse em conhecer com maior detalhe o que acontecia "do outro lado". Alguns, já tendo estado em uma delegacia como vítimas ou como detidos, gostariam de entender como o policial se sente e quais são os recursos com os quais conta, para registrar uma ocorrência.

"C., 52 anos, achou que seria uma oportunidade de poder falar tudo aquilo que ele achava falho no atendimento de uma delegacia. Ele alega que já foi muitas vezes procurar atendimento e pouquíssimas vezes foi bem atendido" (coordenador de visita à delegacia em Recife).

"Os visitantes eram pessoas que já tinham tido contato com a polícia e, nesse caso, em geral, o senso comum impera de maneira abrangente. Mesmo assim, o senso crítico, mesmo baseado no senso comum, traz discursos interessantes: 'como é que o governo quer cobrar as coisas desse pessoal... eles trabalham em péssimas condições... isso deve dar mau humor na pessoa... aí, chega um pra ser atendido e trata os outros mal... tem que ver o lado deles também..." (coordenador de visita à delegacia no Rio de Janeiro).

Para muitos, contudo, a participação na "Semana de visitas" é derivada do desejo de pressionar a polícia por melhorias na qualidade do atendimento prestado. Neste sentido, cumpre destacar as citações que enfatizavam a dimensão de controle civil da ação policial vis-à-vis a possibilidade de exercício da cidadania.

"Quando questionados sobre as razões para participar do projeto, os três voluntários disseram estar interessados em conhecer de perto o funcionamento da delegacia e o trabalho da polícia civil. Além disso, um dos integrantes do grupo disse que o projeto também permitiria exercer sua cidadania, avaliando os serviços que são prestados ao público e cobrando melhorias dos responsáveis" (coordenador de visita à delegacia em São Paulo).

“Para os visitantes, participar da 'Semana de visitas' é também exercer a cidadania, pois o cidadão pode fiscalizar o trabalho da delegacia e a sua relação com a comunidade" (coordenador de visita à delegacia no Rio de Janeiro).

"Os três visitantes resumiram as suas opiniões da seguinte maneira: Visitante 1: 'Sou estudante de serviço social, nunca havia visitado uma delegacia, fiquei com vontade de conhecer. É interessante termos a oportunidade de avaliar um serviço público'; Visitante 2: 'Porque acho que essa é uma forma de colaborar com a mudança e 
promover a garantia dos direitos das pessoas. É uma forma de darmos nossa contribuição'; Visitante 3: 'É uma questão de cidadania, uma vez que a cidadania não é só exigir, mas é também participar e essa é uma forma de participarmos'" (coordenador de visita à delegacia em São Paulo).

A participação dos visitantes em distintas edições da "Semana de visitas" poderia auxiliá-los a compreender como os distritos policiais percebem esse exercício contínuo da cidadania e, dessa forma, alteram os serviços de acordo com as demandas por eles vocalizadas. Nesse sentido, as citações abaixo destacam como as delegacias de polícia mudaram algumas dimensões em sua prática cotidiana, mas estão longe de prestarem um serviço que esteja efetivamente adequado às demandas dos cidadãos.

"Mudou para melhor, não só em relação à estrutura que foi inaugurada há dois meses; como também ao tamanho da equipe de policiais; muito mais equipamentos adequados para atender ao público e para os policiais trabalharem (computadores, mesas, cadeiras etc.); melhoria do atendimento especializado para a mulher vítima da violência e à eficiência na conclusão de inquéritos policiais. $O$ único fator que mudou notavelmente para pior foi a menor quantidade de informação disponível para o público" (coordenador de visita à delegacia em Recife).

"Os visitantes acharam que de um ano para o outro não tiveram mudanças significativas. Apenas algumas melhorias na organização da delegacia, facilitando o uso de espaços que no ano passado estavam indisponíveis para uso" (coordenador de visita à delegacia em Belo Horizonte).

"É minha terceira visita a esta delegacia, e não mudou muita coisa desde a última. As promessas para utilização do espaço que está sobrando na delegacia continuam, mas talvez se deva ao fato da rotatividade dos delegados e funcionários, além da falta de verba para isso. Não só nesta delegacia, mas em todas as visitas, o Decap colocou um cartaz com telefone de contato para denúncias, sugestões, etc. Nesta delegacia, o investigador chefe que acompanhou a visita junto com o delegado, ficou falando o tempo todo sobre o mal que as ONGs de direitos humanos são para a sociedade" (coordenador de visita à delegacia em São Paulo).

Logo, verificar se nas avaliações há menção a essa compatibilização - entre atividade policial e demandas dos cidadãos - é importante, pois ajuda a desconstruir o discurso dos delegados em termos do que é enfatizado como possibilidade de mudança e o que realmente é operacionalizado, tal como indicam as citações em seguida:

"Visitei o DP de XXX em 2010. O delegado citou o fato de terem recebido uma nota baixa no ano anterior, mas de forma geral a de- 
legacia manteve seu padrão de atendimento de um ano para outro, não houve mudança substancial" (coordenador de visita à delegacia em São Paulo).

"A mudança observada pelo grupo foi que tudo está bem pior em relação ao ano anterior. A recepção dos policiais, a mobilização da DP para a visita, a presença (neste caso, ausência) do delegado titular..." (coordenador de visita à delegacia no Rio de Janeiro).

"Não foi possível identificar nenhuma mudança positiva nas práticas policias da referida delegacia, no entanto, é possível perceber algumas mudanças negativas, principalmente na estrutura física e, segundo informações do delegado, nas atividades da IV 'Semana de visita', o mesmo participava de palestras em escolas próximas, no entanto, este ano disse não ter nenhuma atividade dessa natureza e ainda fez um comentário desagradável sobre a sua relação com a comunidade: 'nós já não prestamos serviço à comunidade prendendo os filhos deles?!'” (coordenador de visita à delegacia em Recife).

As citações destacadas (tanto as de policiais como as de cidadãos) parecem indicar que, após a apresentação dos resultados, os policiais se veem obrigados a levar em consideração a demanda apresentada pelos cidadãos em sua prática cotidiana como forma de garantir a adequação do serviço prestado aos standards internacionais em termos de funcionamento das delegacias de polícia. Afinal, os avaliadores podem voltar no próximo ano para uma nova visita e rebaixarem a nota da delegacia.

Por outro lado, talvez o que essas citações não sejam capazes de revelar é o grau de consciência dos policiais quanto à sua função de prestação de um serviço público fundamental e que, por isso, dentro da ideia de cidadania, deveria ser realizado de acordo com as demandas da própria comunidade a que ele serve. Desta forma, a pesquisa da Altus, em sua dimensão de intervenção, estaria acionando os mecanismos de supervisão civil do trabalho policial e, por conseguinte, a necessidade de esse ajustamento entre ideias de reforma do trabalho policial e novas práticas ser mais efetivo do que vinha ocorrendo nos últimos anos. Afinal, a avaliação seguinte pode apontar essa dissonância e, por conseguinte, aumentar as críticas que os delegados procuram evitar. ${ }^{16}$

Logo, não se trata de afirmar que a "Semana de visitas" por si só desperta o desejo de os policiais alterarem os padrões de operação utilizados na realização de suas atividades cotidianas. Mesmo assim, apesar de a organização policial ser bastante refratária a mudanças, em razão dos distintos planos nacionais de segurança pública editados pelo governo federal com seções específicas relacionadas à reforma das polícias, ${ }^{17}$ a polícia civil tem sido obrigada a sair do paradigma de repressão do crime para um paradigma de gestão da ordem pública que concilie os princípios legais com as demandas dos cidadãos.
16. Questões semelhantes foram constatadas na pesquisa realizada com Sadek (2003) sobre trajetória e pensamento dos delegados de polícia. Nesse estudo, a autora pôde constatar que, em que pese a consciência desses profissionais sobre os problemas que comprometem a qualidade do serviço policial prestado pelas delegacias, eles procuram minimizar a visibilidade desses e, dessa forma, afastar as críticas e as pressões por mudanças na forma de estruturação e nos resultados do serviço policial.

17. A este respeito, cf. Adorno (2005). 
Neste contexto, a "Semana de visitas a delegacias de polícia", cuja última fase é o workshop de devolução de resultados, potencializa este efeito ao denotar como os cidadãos percebem as fragilidades dos serviços policiais e como eles se percebem enquanto agentes que podem potencializar a institucionalização dos mecanismos de responsabilização dos policiais pelos serviços prestados.

\section{Considerações finais}

No início do trabalho foi apresentada a obra Direito e sociedade: a transição ao sistema jurídico responsivo, de Nonet e Selznick, recentemente traduzida para o português. Tal obra foi destacada pela classificação que propõe para os sistemas jurídicos baseada em três tipos ideais de direito: direito repressivo, direito autônomo e direito responsivo.

O objetivo deste estudo foi mostrar que, apesar de inseridas num paradigma pensado para dar conta das transformações das instâncias propriamente jurídicas dos Estados Unidos na segunda metade do século passado, as categorias desenvolvidas por Nonet e Selznick poderiam ser úteis para analisar, no Brasil, o comportamento daquela que é considerada a "porta de entrada" do sistema jurídico criminal: a polícia.

Com base nos resultados da "Semana de visitas a delegacias de polícia", cujas atividades se estenderam em 64 delegacias de polícia entre os anos de 2009 e 2011, nas cidades de Recife, São Paulo e Rio de Janeiro, o trabalho buscou refletir em que medida as delegacias participantes dessa pesquisa estavam caminhando, ou não, em direção a um paradigma de direito responsivo. Isto é, um paradigma em que a relação entre as instituições jurídicas e a sociedade é uma relação de maior transparência e permeabilidade em ambas as direções. Essa avaliação foi possível notadamente em razão da natureza da "Semana de visitas". O projeto busca ser um instrumento de análise acadêmica do serviço prestado pelas delegacias, bem como um mecanismo de intervenção e mudança da realidade da polícia ao oferecer às delegacias um retorno das avaliações realizadas pelos potenciais usuários do serviço. Com isso, espera-se viabilizar a melhoria da qualidade do atendimento prestado à comunidade, em consonância com os problemas ressaltados pela própria comunidade na avaliação da delegacia. A "Semana de visitas" concretizaria, portanto, uma lógica de funcionamento cara a um modelo responsivo, em que as instituições jurídicas absorveriam as demandas sociais como forma de autocorreção e aprimoramento de suas tarefas.

Essa tendência foi, de fato, observada, pois a análise longitudinal dos dados coletados ao longo de três anos (2009 a 2011) demonstrou uma melhoria nas avaliações das delegacias. Para além dessa dimensão quantitativa, as referências qualitativas da pesquisa também reforçam essa tendência, pois o que se observa nos discursos, tanto 
dos visitantes quanto dos delegados, é que há, em ambos os lados, a consciência de que a avaliação contínua das delegacias pela sociedade permite o diagnóstico de problemas e cobrança de melhorias ao longo dos anos, que se traduzem na mensuração quantitativa e qualitativa do desempenho da polícia de cada localidade.

Tudo isso parece indicar, também na polícia brasileira, o direcionamento a um sistema responsivo, tal qual observado por Nonet e Selznick quanto ao sistema jurídico norte-americano. Mesmo assim, este é apenas um lado do quadro diagnosticado, pois, junto ao movimento observado da responsividade, perduram traços de uma polícia de atuação arbitrária e autoritária, característica de sistemas jurídicos repressivos.

Nesse sentido, é bom lembrar que os modelos de direito propostos por Nonet e Selznick são tipos ideais e, como tais, não representam realidades concretas, mas apenas a radicalização de algumas características presentes em quaisquer manifestações concretas desses tipos. Isto é, qualquer sistema jurídico contará tanto com dimensões repressivas, quanto com instrumentos de autonomia e capacidade de responsividade. O que permite caracterizar, portanto, um sistema jurídico como repressivo, autônomo ou responsivo é apenas a prevalência de uma dessas dimensões e não a total ausência das demais.

Assim, ao transportar esse quadro analítico para a observação da polícia brasileira o que se percebe é que a instituição de uma lógica responsiva, e mesmo autônoma, ainda precisa conviver com e enfrentar um contexto fortemente repressivo. Nesse cenário, é sintomática a sua regulação ainda em consonância principalmente com os códigos penal e processual penal oriundos de período caracterizado pela relação entre direito e sociedade que Nonet e Selznick apontam como presente principalmente nos quadros de um direito repressivo, qual seja: a instituição de uma ordem política pela força, caso do Estado Novo varguista. Com isso, apesar do relativo sucesso de práticas mais responsivas como as engendradas pela "Semana de visitas", uma legislação e uma cultura policial ainda fortemente influenciadas pelo autoritarismo impedem que, no que tange à força policial, o sistema jurídico brasileiro possa ser caracterizado como eminentemente responsivo.

Talvez, problemas que perpassam esse salto de um direito eminentemente repressivo para um direito eminentemente responsivo, no que tange à polícia, tenham a ver com a negligência para com o estágio de direito que Nonet e Selznick apontam como intermediário entre os dois: o direito autônomo.

As instituições policiais, estando, como destacado anteriormente, em contado direito com os cidadãos 24 horas por dia, nunca poderiam gozar do mesmo nível de autonomia de outras instituições jurídicas, como os tribunais. Por conta disso, tais agências, 
na sua necessidade de lidar mais diretamente com o público, tenderiam a apresentar traços ou mais repressivos ou mais responsivos, tendo dificuldades para desenvolver uma maior autonomia perante seu entorno social. Mesmo assim, torna-se difícil superar uma lógica repressiva em direção a uma lógica responsiva, se não se levar a sério algumas dimensões importantes do direito autônomo, como a manutenção do devido processo legal e uma lógica de governo de "leis e não de homens".

Como apresentado no início do trabalho, em citação dos próprios Nonet e Selznick, o direito responsivo não é simplesmente um direito aberto, ou adaptável, mas sim um direito que se abre a seu entorno de maneira responsável, repeitando os propósitos que o mantêm íntegro. Logo, não será uma polícia responsiva, dentro do estabelecido por Nonet e Selznick, uma polícia que simplesmente se abra à sociedade, ouça o que ela tem a dizer e se transforme com base nisso, se ela não tiver certa autonomia baseada em sua peculiaridade como instrumento de força juridicamente tutelado. 0 que os autores chamam de manutenção da integridade do direito baseada na fidelidade a seus propósitos pode ser repassado às instituições policiais no respeito, por exemplo, à defesa dos direitos humanos e tratamento igualitário.

Por conseguinte, uma polícia que ainda atue repressivamente com base em critérios pessoais - como classe social ou cor da pele - e não parâmetros legais, e que faça uso de tortura e execução sumária, em detrimento do devido processo legal, não reconheceu suficientemente a sua autonomia, isto é, o que a distingue como parte de um sistema jurídico para a administração de conflitos entre cidadãos e não como força militar de eliminação de "inimigos da ordem". Por isso, essa mesma polícia, persistindo em tais vícios, por mais que venha a ser aberta e adaptável, não conseguirá ser verdadeiramente responsiva.

Abstract: In this article, we will focus the relationship between society and State using Nonet and Selznick's ideas of repressive, autonomous and responsive law to understand the transformations of "Civilian Police" in three Brazilian states - São Paulo, Rio de Janeiro and Pernambuco - using the data obtained in the research "Police Stations visitors Week", that evaluates the police districts in terms of community orientation, physical conditions, equal treatment of people, transparency and accountability, conditions of detention and, after that, discuss the results with the chiefs of police, enabling positive changes in the services offered by police to community. Based on the data collected in 64 police stations visited in Pernambuco, Sao Paulo and Rio de Janeiro, in three consecutive years (20092011), and considering the improvement in the quality of service provided to population, we discuss how the police have became more permeable and responsive to society, despite the persistence of strong repressive traits, such as the weight of the function of order enforcement and a policy of treating the work of police institutions as a secret of State.

Keywords: Responsive Law. Repressive Law. Police Stations. "Police stations Visitors Week". 


\section{Referências}

AlEXY, Robert. Conceito e validade do direito. São Paulo: Martins Fontes, 2009.

Altus. Police station visitors week: global report 2011. New York: Vera Institute of Justice, 2012.

DWORKIN, Ronald. O império do direito. São Paulo: Martins Fontes, 2003.

HABERMAS, Jürgen. Between facts and norms: contributions to a discourse theory of law and democracy. 3. ed. Cambridge: MIT Press, 1999.

KANT DE LIMA, Roberto. A polícia da cidade do Rio de Janeiro: seus dilemas e paradoxos. Rio de Janeiro, Forense, 1995.

MingardI, Guaraci. Tiras, gansos e trutas, cotidiano e reforma da polícia civil. São Paulo, Scritta, 1982.

MISSE, Michel. Crime, sujeito e sujeição criminal: aspectos de uma contribuição analítica sobre a categoria "bandido". Lua Nova [Online]. n. 79. São Paulo, 2010, p. 15-38.

MISSE, Michel; PAES, Vivian. O Programa Delegacia Legal no Rio de Janeiro: avaliação de uma experiência modernizadora na polícia civil brasileira. Rio de Janeiro: Núcleo de Estudos da Cidadania, Conflito e Violência Urbana/ UFRJ, s/d, mimeo.

Nonet, Philippe; Selznick, Philip. Direito e sociedade: a transição ao sistema jurídico responsivo. Rio de Janeiro: Revan, 2010.

PAIXÃo, Antônio Luiz. A organização policial numa área metropolitana. Dados, v. 25, n. 1. Rio de Janeiro, 1982.

Peralva, Angelina. Perspectives sur la violence brésilienne. Tiers-Monde. Tome 42, n. 167. Paris, 2001, p. 537-554.

Poncioni, Paula. A polícia e os pobres: representações e práticas em delegacias de polícia do Rio de Janeiro. 1995. Dissertação (Mestrado) - Escola de Serviço Social, Universidade Federal do Rio de Janeiro, Rio de Janeiro.

RIBEIRO, Ludmila ; SILVA, Klarissa. Desafios aos direitos humanos e à justiça no Brasil: uma análise da qualidade do atendimento prestado pelas delegacias de polícia. E-cadernos CES [Online], v. 8. Coimbra, 2011, p. 92-114.

RIBEIRO, Ludmila; DUARTE, Thais Lemos. Do processo penal colonial à reforma processual penal de 2008: análise sócio-histórica do sistema de justiça criminal brasileiro. Interseções (UERJ), no prelo, 2011. 
SADEk, Maria Tereza. Delegados de polícia. São Paulo: Sumaré/Idesp, 2003.

SinhoretTo, Jacqueline. A justiça perto do povo: reforma e gestão de conflitos. São Paulo: Alameda, 2011.

SOARES, Luiz Eduardo. Meu casaco de general: quinhentos dias no front da segurança pública no Rio de Janeiro. São Paulo: Companhia das Letras, 2000. 